\title{
Comparative Life Cycle Assessment of Lightweight Aggregates Made from Waste-Applying the Circular Economy
}

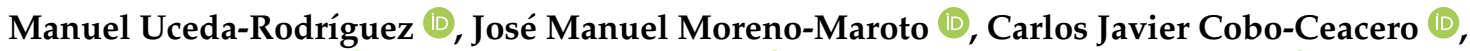 \\ Ana B. López-García (1), Teresa Cotes-Palomino (1) and Carmen Martínez-García *(1)
}

check for

updates

Citation: Uceda-Rodríguez, M.;

Moreno-Maroto, J.M.; Cobo-Ceacero,

C.J.; López-García, A.B.;

Cotes-Palomino, T.; Martínez-García,

C. Comparative Life Cycle

Assessment of Lightweight

Aggregates Made from

Waste-Applying the Circular

Economy. Appl. Sci. 2022, 12, 1917.

https://doi.org/10.3390/app12041917

Academic Editor: Fernanda Andreola

Received: 6 December 2021

Accepted: 10 February 2022

Published: 12 February 2022

Publisher's Note: MDPI stays neutral with regard to jurisdictional claims in published maps and institutional affiliations.

Copyright: () 2022 by the authors Licensee MDPI, Basel, Switzerland. This article is an open access article distributed under the terms and conditions of the Creative Commons Attribution (CC BY) license (https:// creativecommons.org/licenses/by/ $4.0 /)$.
Department of Chemical, Environmental and Materials Engineering, Higher Polytechnic School of Linares, Scientific and Technological Campus of Linares, University of Jaen, 23700 Linares, Jaén, Spain; muceda@ujaen.es (M.U.-R.); jmmaroto@ujaen.es (J.M.M.-M.); cjcobo@ujaen.es (C.J.C.-C.); ablopez@ujaen.es (A.B.L.-G.); mtcotes@ujaen.es (T.C.-P.)

* Correspondence: cmartin@ujaen.es

\begin{abstract}
The application of Life Cycle Assessment in the construction sector can be a very useful tool to reduce the environmental impact generated by the sector. In order to quantify the improvement in environmental terms with the use of artificial lightweight aggregates (LWA) manufactured with waste, in this work, we conducted a comparative evaluation of the life cycle of LWAs for a total of five different scenarios: LWAs obtained in a traditional way, i.e., using exclusively clay in their manufacture (Spanish blond clay, Portuguese red clay and Portuguese blond clay), and LWAs manufactured with four different wastes, with a partial substitution of $2.5 \%$ for each of the clays per waste (almond and hazelnut shells, sludge from the purification of paper money, cork dust and coffee grounds). The functional unit was set as the production of 1 kilo of lightweight aggregates and the CML 2000 methodology and the SimaPro software were used. The results obtained in this research allow us to conclude that the addition of organic wastes showed a slightly higher environmental performance than the conventional system, the ALAs manufactured with almond and hazelnut shells being the most environmentally friendly option, with reductions of more than $30 \%$ in some cases, followed by the LWAs manufactured with coffee grounds. On the other hand, the addition of paper sewage sludge and cork dust represents minimal environmental optimization.
\end{abstract}

Keywords: life cycle assessment; industrial waste; circular economy; lightweight aggregate; waste recycling

\section{Introduction}

The Circular Economy (CE) is profoundly changing the pillars of traditional industry. The industrial sector, as well as society in general, is increasingly aware of the importance of addressing the efficient use of resources and raw materials, as well as the impact of high emissions of harmful substances associated with human activity on the environment, public health, resource value and economic development [1]. The Circular Economy aims to make better use of resources/materials through reuse, recycling and recovery, and also to minimize the energy and environmental impact of resource extraction and processing. The application of this approach is paramount in areas such as bioindustry, bioenergy and the construction sector [2-4].

CE-based product design focuses on multifunctional goods, extending the useful life of products and their parts and smart manufacturing to help industries maximize product utility while providing long-term economic, environmental and societal protection by giving waste a key role and producing new technological products from it, while reducing the use of raw materials and energy and avoiding emissions to the environment by enterprises [5]. Recycling waste into new products conserves the energy embodied in the initial material. This energy, in the case of building materials, represents an important 
part of the life cycle impacts of the building. Recycling waste into new products conserves the energy embedded in the initial material. This energy, in the case of building materials, represents an important part of the impacts of the building's life cycle.

In order to achieve a scenario where waste is no longer waste but a raw material or technological nutrient, extensive research is needed. It is necessary to establish a methodology that allows, based on the characterization of the waste, to determine its advantages and disadvantages in order to derive it towards the production processes that are best adapted to its characteristics. This will make it possible to obtain materials or products with the highest possible added value using the best available technologies. In this way, polluting emissions would be reduced at the same time. This commitment to the Circular Economy, increasingly supported by organizations and countries through directives, decrees and specific regulations, is leading society towards the goal of zero waste [6]. In this sense, the new Circular Economy Action Plan 2020 has been designed to boost the EU's growth, competitiveness and global leadership in this field [7].

The construction industry is one of the most polluting sectors, with great efforts being invested in the development of new methods or materials that reduce its high dependence on energy and natural resources [8]. Aggregate, the most used material in construction and the second most consumed raw material by humans after water [9], is responsible for significant environmental impacts due to the overexploitation of natural quarries and gravel pits. Its multiple uses, not only in construction, but also in industry, agriculture and environmental protection, give it a strategic character. The manufacture of artificial aggregates — and more specifically, artificial lightweight aggregates (LWAs) can be considered as a possible alternative to the use of natural aggregates. LWAs are generally obtained by thermal expansion of clay materials at high temperatures [10]. Its final properties make it an ideal material for a wide variety of applications due to its low density, insulating capacity, water absorption and inert character [11,12]. Some of these applications are green roofs; substrates for horticulture and hydroponic crops; engineering applications such as lightweight concrete, pavements and filter media; and geotechnical applications.

An alternative to the traditional manufacture of artificial lightweight aggregates consists of replacing part of the clayey raw material with waste from different sources. In recent years, the number of articles published on waste recycling in the manufacture of LWAs has multiplied [13]. Some of these wastes are of organic character, such as sawdust, coffee grounds, processed corn cob granulate, brewing industry wastes, coconut, cotton, rice or meat bone meal [14-18]. Others are of an inorganic nature, such as copper heavy metals, glass waste, coal ash or clay by-products from phosphate mines [19-22]. The recycling of these wastes in the artificial aggregate will contribute to reach the goal of zero waste as long as the final product obtained complies with the required quality standards.

To this end, our research group has developed a series of LWAs in which part of the traditional raw material (three clays of different origin that do not tend to expand) is replaced with the following four wastes: almond and hazelnut shells (AHS), sludge from the purification of paper money (PS), cork dust (CP) and coffee grounds (CG). The incorporation of these wastes in a proportion of $2.5 \%$ by weight has made it possible to obtain materials classified as light aggregates according to EN-13055-1, 2002 [12], as they all have loose bulk and oven dry densities of less than 1200 and $2000 \mathrm{~kg} / \mathrm{m}^{3}$, respectively. The first residues, almond and hazelnut shells (AHS), come from the industry that prepares nuts for consumption. Spain is the third-largest producer of almonds (48,000 tons in 2014/2015) and sixth in hazelnut production worldwide (9750 tons in 2014/2015) [23,24], generating a total of 6000 tons of waste annually [25]. This organic residue is currently being used as an excipient in the manufacture of medicines, biomass [26], flours and base for metal adsorption $[27,28]$. No literature has been found on the use of this residue in the manufacture of LWAs. Paper money sewage sludge (PS) is obtained in the process of purifying wastewater generated in the manufacture of paper money from cotton linters. The amount of waste generated per year in the paper industry is about 1.45 million tons compared to 7.5 million tons of manufactured paper, of which more than 5.5 million tons would be recovered again 
as recycled paper [29]. This waste is of a mixed nature, although the high load of organic matter it contains offers great advantages for its valorization. At present, the destination of this waste is the landfill, and the consequent environmental impact that this entails fuels the incentive to take advantage of this material with a view to its valorization. Another waste used as an additive is $\mathrm{CP}$, which mainly comes from the manufacture of cork stoppers, as well as agglomerates and products for thermal and acoustic insulation [30]. Current Mediterranean cork production is estimated at 185,000 tons/year in Portugal alone, which accounts for more than $50 \%$ of global production. From this amount, 40,000 tons/year of residual cork dust are generated, which, having an average particle size too low for the manufacture of agglomerates, is mainly destined for the energy market [31]. However, the use as fuel, in addition to having a negative environmental and economic impact, does not seem to be the most appropriate for a material that has great aptitude for being recycled into products with high added value.

The last of the residues, CG, is obtained during the treatment of ground coffee beans with hot water or steam for the preparation of instant coffee. Coffee is the second-most traded product after petroleum worldwide, so the generation of waste from the coffee industry is very high [32]. This amount is 6 million tons globally [33], and it is estimated that the production of one ton of green coffee generates about $650 \mathrm{~kg}$ of coffee grounds [34]. This residue has a fine particle size, high humidity (greater than $80 \%$ ) and an acidic $\mathrm{pH}$. However, the main problem with this residue is its high level of organic load, as well as the presence of compounds such as caffeine, tannins and polyphenols in significant quantities, thus requiring a large volume of oxygen for its degradation. This makes landfilling not a simple disposal alternative as in other waste materials, there being a high probability of spontaneous combustion when deposited in large quantities [35]. On the other hand, because it is a waste that is produced in high quantities worldwide, it can be positioned as a possible alternative in large tonnage applications such as civil engineering or the construction industry [36].

Once the materials have been obtained under optimal manufacturing conditions, it is interesting to quantify the environmental benefit of using waste as raw materials in the manufacture of LWAs. For this purpose, the Life Cycle Assessment (LCA) methodology has been applied. LCA is currently one of the most widely used methods to assess the environmental impact of the manufacture of a given product on the environment. LCA is an analytical tool that captures the overall environmental impact of a product, process or human activity from raw material acquisition, through production and use, on waste management. This global view makes the LCA unique in the environmental management toolkit, being one of the most widely used methods for assessing the environmental impact of the manufacture of a given product on the environment [37]. The ISO 14040 and 14044 standards are responsible for standardizing their application through four key steps: definition of the objective and scope, inventory analysis, impact analysis and interpretation of the results [38,39]. Their main function is to establish a common basis from which to establish the inputs and outputs to the biosphere and technosphere of the product.

The objective of this work is to carry out a comparative LCA study between the LWAs manufactured with partial replacement of the clay material by the indicated wastes versus the LWAs obtained in the traditional way using clay exclusively. The aim of this study is to demonstrate the environmental benefit that can be achieved through the recycling of waste into construction materials using an objective tool, LCA. Although LCA is increasingly being used to analyze the life cycle of construction materials [40-42], there are few articles published to date that carry out a comparative study as presented in this work $[43,44]$.

\section{Methodology}

\subsection{Manufacture of LWAs from Wastes}

In this study, artificial lightweight aggregates (LWAs) have been developed that incorporate non-hazardous organic waste in a percentage of $2.5 \%$ by weight. The addition of this 
type of waste has made it possible to obtain a material that complies with the specifications established by European regulations to be considered as lightweight aggregates [12,37].

\subsubsection{Raw Materials}

For the preparation of the LWAs, mixtures of three different clays with four types of industrial organic waste were used. The three different clays were a Spanish yellow clay (SY) supplied by the company Comercial Cerámicas de Bailén, S.A. (Bailén, Jaén, Spain) and two Portuguese clays, a red clay (PR) and a yellow clay (PY), supplied by Corbário Minerais Industriais S.A. (Colmenas, Portugal). Four different types of waste were used: almond and hazelnut shells (AHS) supplied by Unió Corporació Alimentària de Reus (Catalonia, northern Spain), wastewater sewage sludge from the manufacture of paper money (PS) supplied by CELSUR (Andalusia, southern Spain), cork dust (CP) supplied by EUROTAPÓN NÚÑEZ, S.L. (Extremadura, western Spain) and lastly, coffee grounds (CG) supplied by the Portuguese company DELTA Cafés.

\subsubsection{Manufacture of LWAs}

The LWA manufacturing process was carried out following the working protocol published in previous studies by this same research group [45,46]. Mixtures of clay and organic residue were prepared in percentages of $97.5 \%$ and $2.5 \%$, respectively. The proportion of organic residue used is based on the authors' previous experience with this type of high-carbon waste [45]. Thus, once the raw material mixture was prepared in the indicated proportion, the appropriate moisture content was added, and after $24 \mathrm{~h}$ in resting conditions, the mixture was extruded using a Nannetti ${ }^{\circledR}$ laboratory pneumatic extruder, obtaining thin cylinders of $8-10 \mathrm{~mm}$ in diameter. The extruded material was cut and shaped into spherical pellets of approximately $10.2 \mathrm{~mm}$ in diameter. They were then dried for $24 \mathrm{~h}$ at room temperature, and then dried in an oven at $105^{\circ} \mathrm{C}$ for $24 \mathrm{~h}$. Once dried, the pellets obtained were fired in a Nannetti ${ }^{\circledR}$ TOR-R 120-14 rotary tubular kiln with a rotation speed of $2.5 \mathrm{rpm}$, using the following protocol: 1 or $2 \mathrm{~min}$ in the preheating zone of the furnace at a temperature between 600 and $800{ }^{\circ} \mathrm{C}$, an intermediate step necessary to prevent the material from bursting, and $4 \mathrm{~min}$ in the central zone of the furnace at the maximum firing temperature. This maximum temperature was determined for each mixture according to Moreno-Maroto et al. (2019) [45,46]: the maximum temperature that the material can reach without melting or sticking to the kiln tube or other pellets. In this way, the maximum expansion that the initial pellet can undergo when transformed into LWA can be observed.

The added wastes not only play a crucial role in the bloating process of the aggregate, but due to their organic character, they also have significant calorific value. This is advantageous from energy and environmental perspectives. On the one hand, the combustion of the organic waste will bring heat to the process, which means less fuel consumption during the firing of the aggregates. On the other hand, and directly related to this reduction, there will be a decrease in greenhouse gas emissions. Both aspects will provide an environmental benefit that will be reflected in the LCA of the materials manufactured. Table 1 shows the gross and net calorific values of the waste used in this work, determined according to standard EN 14918 [47].

Table 1. Gross and net calorific values of wastes $(\mathrm{GCV}=$ gross calorific value; NCV $=$ net calorific value).

\begin{tabular}{ccc}
\hline Waste & GCV (kJ/kg) & NCV (kJ/kg) \\
\hline AHS & $19,005.9$ & $17,763.6$ \\
\hline PS & $12,901.7$ & $11,836.9$ \\
\hline CP & $29,096.3$ & $27,340.5$ \\
\hline CG & $20,961.8$ & $19,463.8$ \\
\hline
\end{tabular}


In total, we worked with 15 types of samples grouped into 5 different scenarios: a first scenario corresponding to aggregates obtained exclusively from clay and the remaining four depending on the organic additive used. Table 2 shows the firing conditions for each of the working samples.

Table 2. Mixtures and firing conditions $\left(t_{\text {preh }}=\right.$ preheating time in the kiln inlet; $t_{\text {firing }}=$ firing time in the middle of the kiln; $\mathrm{T}_{\max }=$ maximum temperature reached in the middle of the kiln).

\begin{tabular}{|c|c|c|c|c|}
\hline Waste & Sample Code & $t_{\text {preh }}$ (Min) & $\mathbf{t}_{\text {firing }}($ Min) & $\mathrm{T}_{\max }\left({ }^{\circ} \mathrm{C}\right)$ \\
\hline & SY-0 & 1 & 4 & 1180 \\
\hline & PY-0 & 1 & 4 & 1210 \\
\hline & PR-0 & 1 & 4 & 1350 \\
\hline \multirow{3}{*}{ AHS } & SY-2.5AHS & 1 & 4 & 1180 \\
\hline & PY-2.5AHS & 1 & 4 & 1180 \\
\hline & PR-2.5AHS & 1 & 4 & 1315 \\
\hline \multirow{3}{*}{ PS } & SY-2.5PS & 1 & 4 & 1190 \\
\hline & PY-2.5PS & 2 & 4 & 1160 \\
\hline & PR-2.5PS & 1 & 4 & 1315 \\
\hline \multirow{3}{*}{$\mathrm{CP}$} & SY-2.5CP & 1 & 4 & 1195 \\
\hline & PY-2.5CP & 2 & 4 & 1160 \\
\hline & PR-2.5CP & 1 & 4 & 1315 \\
\hline \multirow{3}{*}{ CG } & SY-2.5CG & 1 & 4 & 1180 \\
\hline & PY-2.5CG & 2 & 4 & 1180 \\
\hline & PR-2.5CG & 1 & 4 & 1315 \\
\hline
\end{tabular}

\subsection{Life Cycle Assessment of Lightweight Aggregates Containing Different Wastes}

The overall purpose of LCA is to evaluate the flows of material and energy inputs to establish the environmental impact of a product, good or service. To achieve this goal, the life cycle is decomposed into a series of stages. In the specific case of products, these stages are raw materials, extraction of raw materials, preliminary transport, manufacture or assembly, subsequent transport, useful life and end of life. The end of life can be divided into disassembly and re-entry into the circle (Circular Economy) or removal to landfill (Linear Economy). Depending on the number of stages analyzed, a finite set of stages will be chosen.

\subsubsection{Objective and Scope Definition}

The specific objective of this work is to carry out a comparative LCA study between LWAs manufactured with partial substitution of the traditional raw material (clay) by waste materials and LWAs obtained exclusively from clay, with the aim of highlighting the environmental benefits of recycling waste into construction materials.

The functional unit set in this study is the analysis of $1 \mathrm{~kg}$ of artificial lightweight aggregates with a bulk density between 400 and $1200 \mathrm{~kg} / \mathrm{m}^{3}$ [12,36]. Once the LCA was obtained for each type of aggregate, the comparative study between them was carried out.

Figure 1 shows the limits of the system. A "cradle-to-gate" approach has been established, since a complete approach including the end-of-life stages and end-of-use scenario would not present any difference with respect to that of traditional aggregate. 


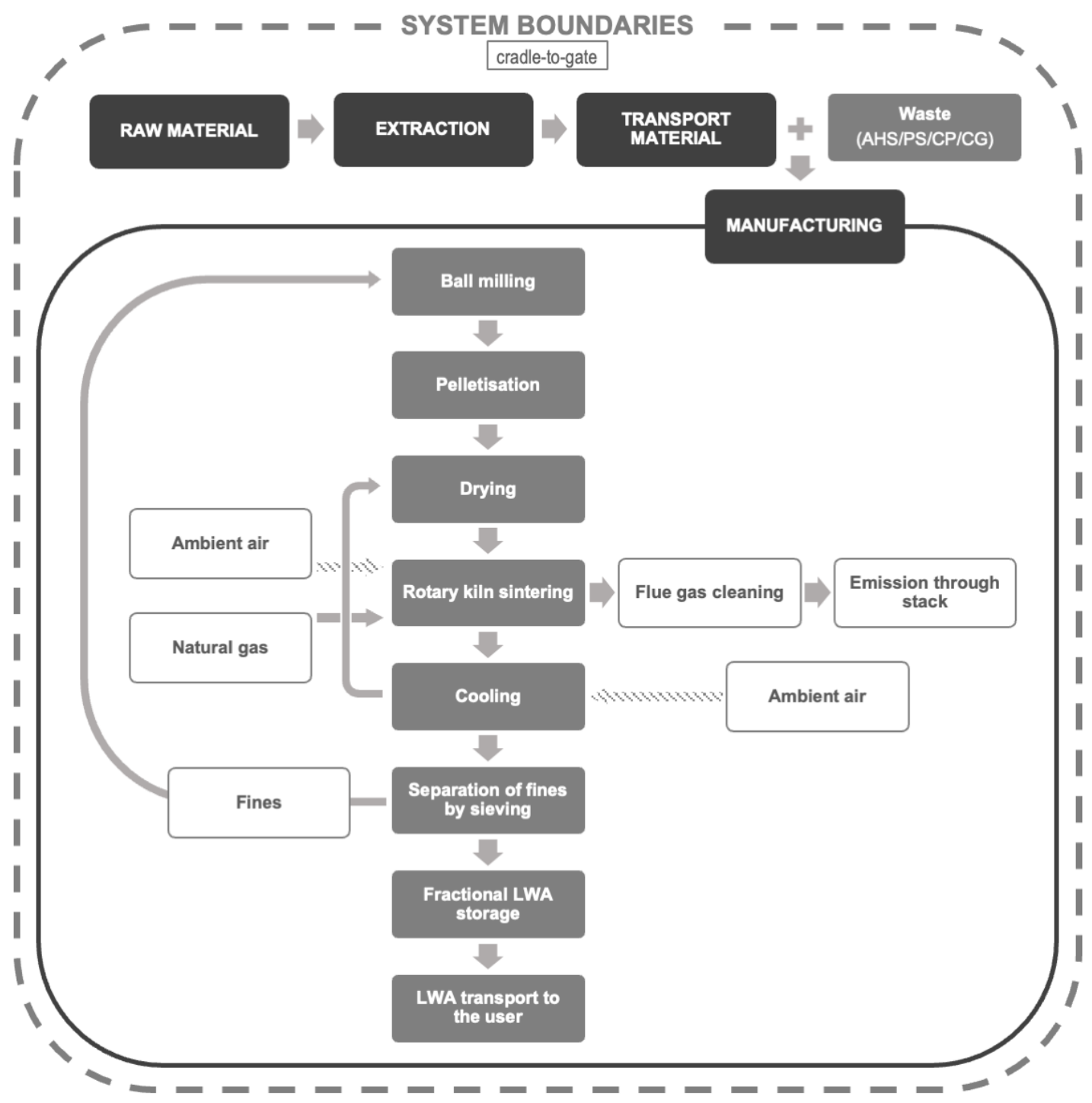

Figure 1. Artificial lightweight aggregate production scheme and system boundaries considered.

The stages studied were as follows:

- Raw materials. This stage includes the basic materials necessary for the manufacture of aggregates, such as clays and the four wastes to be studied. This stage would also contain the water necessary for the process. The wastes have been considered as processes with zero environmental load. This is because the environmental load associated with their production would correspond to the main product and not to the waste derived from the process.

- Extraction. This stage contains the processes carried out in the vicinity of the quarry, such as the occupation of the land in the extraction area and the energy required in the process.

- Transportation. This stage includes the transportation of the raw material to the factory and of the final product to its destination. For the latter, road transport has been considered, with $6 \%$ by delivery van for goods with a large share of retail sales, and $3 \%$ for goods that are mainly sold wholesale. This differentiation is indicated in the process description selected from the Ecoinvent v3 database $[48,49]$.

- Manufacturing. The last manufacturing stage contains the processes necessary for the production of the resulting aggregate, as well as the additional materials demanded by the machinery used and its packaging. It would also include the energy required to carry out the process and the emissions generated to air and water. 
The successive stages of useful life and end of life have been excluded, since there would be no differentiation, as they are not susceptible to variations with respect to the nature of the aggregates.

Of the different scenarios considered, a maximum radius of action of $50 \mathrm{~km} / \mathrm{m}$ has been assumed for the transport scenario. Figure 2 shows a summary of the different scenarios considered in this comparative study.

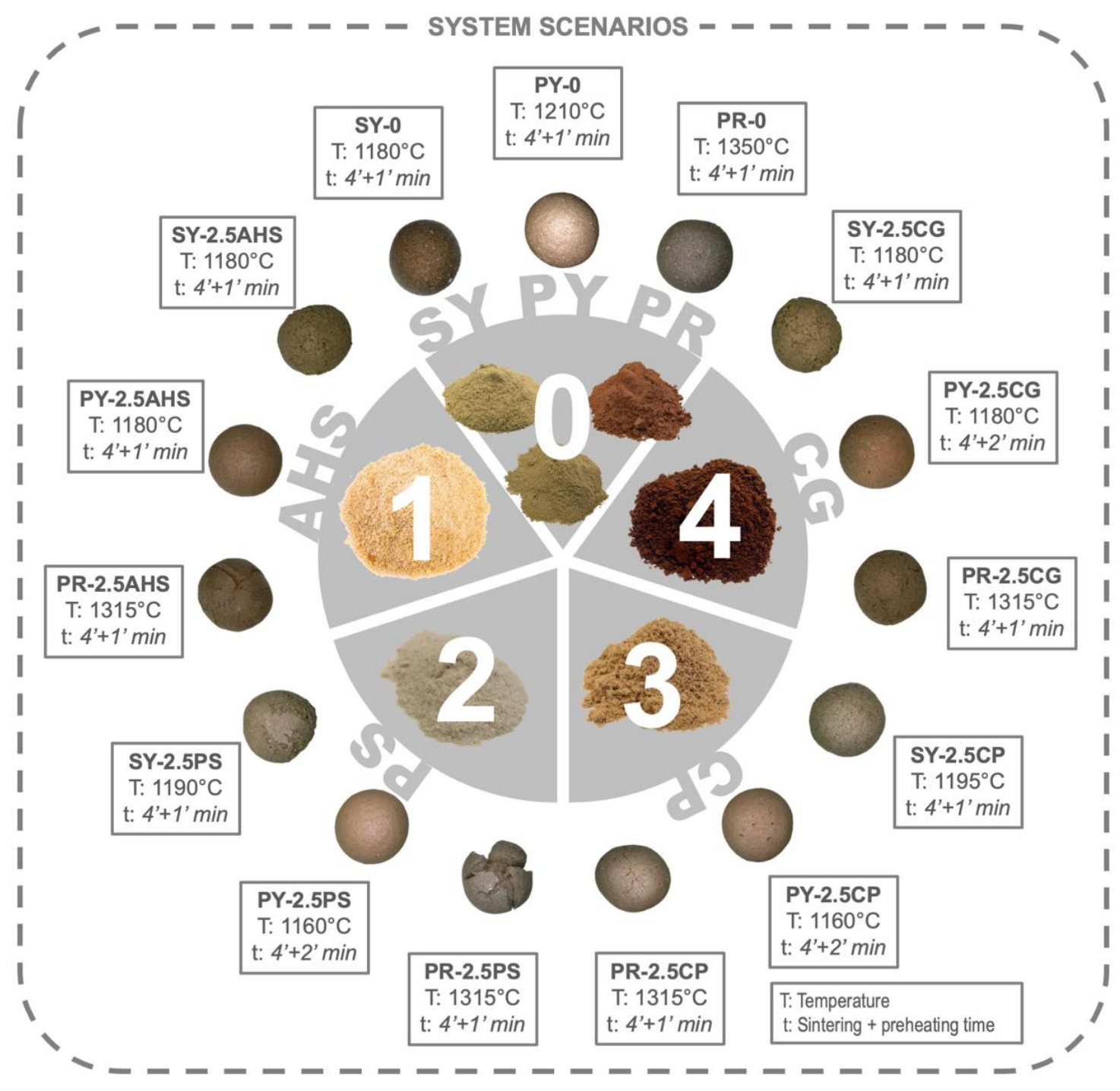

Figure 2. System scenarios considered: (0) LWA from SY, PY and PR without residues; (1) LWA from SY, PY and PR with $2.5 \mathrm{wt} \%$ almond and hazelnut shells (AHS); (2) LWA from SY, PY and PR with 2.5 wt \% paper sewage sludge (PS); (3) LWA from SY, PY and PR with $2.5 \mathrm{wt} \%$ cork dust (CP); (4) LWA from SY, PY and PR with coffee grounds (CG).

\subsubsection{Life Cycle Inventory Assessment}

The data provided in a life cycle inventory must be reliable, i.e., represent reality as closely as possible. This is essential in order to build a solid system model.

To carry out this task, data have been extracted from different sources. These include (i) measured and processed empirical data based on laboratory experimental investigations on raw material ratios, gas emissions and energy consumption; (ii) data from literature sources [49,50]; and (iii) data from the Ecoinvent v3 database [48], to complement background processes. For the latter, we have taken into account those processes similar to the objective and scope pursued in this analysis, as is the case of expanded clay (expanded 
clay production RoW, process identifier: EI3ADUNI000061667503628), which is based on data measured in a global scope and with sintering temperatures close to those used in this study.

Table 3 includes the data that made up the life cycle inventory in this study.

\subsubsection{Life Cycle Impact Assessment Methodology}

The methodology followed, CML 2000 version 2.05, was developed by the Institute of Environmental Sciences of the University of Leiden in 1992. It is midpoint-oriented and analyzes the following impact categories: Abiotic Depletion, Acidification, Eutrophication, Global Warning Potential, One-Layer Depletion, Human Toxicity, Fresh Water Aquatic Ecotox, Marine Aquatic Ecotoxicity, Terrestrial Ecotoxicity and Photochemical Oxidation. Although their regional validity is global in scope, the Acidification and Photochemical Oxidation categories are based on European average values [51].

The choice of this methodology is based on its versatility and efficiency, allowing direct knowledge of four areas of protection, such as human health, the environment, the artificial environment and natural resources. It has been used in numerous articles [52-54].

This methodology allows a standardized evaluation of the impact indices with respect to an average European in a year, with which we can gain a realistic view of the different environmental effects and their relative importance.

The program SimaPro, version 8.3.0.0.0 from PRé Consultants, was used for model building and data processing.

\subsubsection{Contribution and Influence Analysis}

The contribution analysis allows us to know the load that each of the phases of the production process represents to the total of the production process. This influence can be classified according to the following ranges: (i) negligible $(<2.5 \%)$; (ii) minor influence (2.5-5\%); (iii) quite important (5-25\%); (iv) relevant (25-50\%); (v) significant (>50\%) [39]. Similarly, an influence analysis of the results has been carried out, in which the possibility of influencing environmental aspects, either to a lesser or greater degree, is evaluated, arriving at assessing three possible existing alternatives: (A) significant control, with great possible improvements; (B) little control, with some possible improvements; (C) no possible control. This degree of control is oriented to the capacity that the companies have to modify the current production processes. 
Table 3. Most relevant inventory data associated with the production of $1 \mathrm{~kg}$ of lightweight aggregates for the different phases analyzed: raw materials, extraction, transport and manufacture.

\begin{tabular}{|c|c|c|c|c|c|c|c|c|c|c|c|c|c|c|c|c|}
\hline & & & & & & AHS & & & PS & & & CD & & & CG & \\
\hline $\begin{array}{l}\text { Elementary } \\
\text { Flow }\end{array}$ & Units & SY & PY & PR & $\begin{array}{c}\text { SY- } \\
\text { 2.5AHS }\end{array}$ & $\begin{array}{c}\text { PY- } \\
\text { 2.5AHS }\end{array}$ & $\begin{array}{c}\text { PR- } \\
\text { 2.5AHS }\end{array}$ & SY-2.5PS & PY-2.5PS & PR-2.5PS & $\begin{array}{c}\text { SY- } \\
2.5 C D\end{array}$ & $\begin{array}{c}\text { PY- } \\
2.5 C D\end{array}$ & $\begin{array}{c}\text { PR- } \\
2.5 \mathrm{CD}\end{array}$ & $\begin{array}{c}\text { SY- } \\
2.5 C G\end{array}$ & $\begin{array}{c}\text { PY- } \\
2.5 C G\end{array}$ & $\begin{array}{c}\text { PR- } \\
2.5 C G\end{array}$ \\
\hline \multicolumn{17}{|c|}{ Raw materials, extraction and transport } \\
\hline Waste & $\mathrm{kg}$ & - & - & - & 0.025 & 0.025 & 0.025 & 0.025 & 0.025 & 0.025 & 0.025 & 0.025 & 0.025 & 0.025 & 0.025 & 0.025 \\
\hline & $\mathrm{m}^{3}$ & 0.0000736 & 0.0000736 & 0.0000736 & 0.0000736 & 0.0000736 & 0.0000736 & 0.0000736 & 0.0000736 & 0.0000736 & 0.0000736 & 0.0000736 & 0.0000736 & 0.0000736 & 0.0000736 & 0.0000736 \\
\hline Water & $\mathrm{kg}$ & 0.0134 & 0.0134 & 0.0134 & 0.0134 & 0.0134 & 0.0134 & 0.0134 & 0.0134 & 0.0134 & 0.0134 & 0.0134 & 0.0134 & 0.0134 & 0.0134 & 0.0134 \\
\hline $\begin{array}{l}\text { Transport } \\
\text { raw } \\
\text { materials }\end{array}$ & $\mathrm{tkm}$ & 0.0747 & 0.0747 & 0.0747 & 0.0747 & 0.0747 & 0.0747 & 0.0747 & 0.0747 & 0.0747 & 0.0747 & 0.0747 & 0.0747 & 0.0747 & 0.0747 & 0.0747 \\
\hline $\begin{array}{l}\text { Extraction } \\
\text { plant }\end{array}$ & $p$ & $\begin{array}{l}2.00 \times \\
10^{-10}\end{array}$ & $\begin{array}{l}2.00 \times \\
10^{-10}\end{array}$ & $\begin{array}{c}2.00 \times \\
10^{-10}\end{array}$ & $\begin{array}{l}2.00 \times \\
10^{-10}\end{array}$ & $\begin{array}{l}2.00 \times \\
10^{-10}\end{array}$ & $\begin{array}{l}2.00 \times \\
10^{-10}\end{array}$ & $\begin{array}{c}2.00 \times \\
10^{-10}\end{array}$ & $\begin{array}{c}2.00 \times \\
10^{-10}\end{array}$ & $\begin{array}{c}2.00 \times \\
10^{-10}\end{array}$ & $\begin{array}{l}2.00 \times \\
10^{-10}\end{array}$ & $\begin{array}{c}2.00 \times \\
10^{-10}\end{array}$ & $\begin{array}{l}2.00 \times \\
10^{-10}\end{array}$ & $\begin{array}{c}2.00 \times \\
10^{-10}\end{array}$ & $\begin{array}{c}2.00 \times \\
10^{-10}\end{array}$ & $\begin{array}{l}2.00 \times \\
10^{-10}\end{array}$ \\
\hline \multicolumn{17}{|c|}{ Energy and material inputs at LWA manufacturing plant } \\
\hline Electricity & $\mathrm{kWh}$ & 0.028881 & 0.029303 & 0.028881 & 0.015635 & $0.01405^{\circ 0}$ & 0.007351 & 0.021531 & 0.021952 & 2.513513 & 0.006688 & 0.022021 & 0.0216 & 0.014554 & 0.014975 & 0.014554 \\
\hline Heat & MJ & 2.54981 & 2.587017 & 2.54981 & 2.422739 & 2.282864 & 1.691409 & 2.476307 & 0.021531 & 2.476307 & 2.333269 & 2.519572 & 2.482392 & 2.411935 & 2.449116 & 2.411935 \\
\hline $\begin{array}{l}\text { Packaging } \\
\text { film }\end{array}$ & $\mathrm{kg}$ & 0.0004813 & 0.0004813 & 0.0004813 & 0.0004813 & 0.0004813 & 0.0004813 & 0.0004813 & 0.0004813 & 0.0004813 & 0.0004813 & 0.0004813 & 0.0004813 & 0.0004813 & 0.0004813 & 0.0004813 \\
\hline Linerboard & $\mathrm{kg}$ & 0.002 & 0.002 & 0.002 & 0.002 & 0.002 & 0.002 & 0.002 & 0.002 & 0.002 & 0.002 & 0.002 & 0.002 & 0.002 & 0.002 & 0.002 \\
\hline \multicolumn{17}{|c|}{ Emissions from thermal processing of raw materials } \\
\hline Water & $\mathrm{m}^{3}$ & 0.0000067 & 0.0000067 & 0.0000067 & 0.0000067 & 0.0000067 & 0.0000067 & 0.0000067 & 0.0000067 & 0.0000067 & 0.0000067 & 0.0000067 & 0.0000067 & 0.0000067 & 0.0000067 & 0.0000067 \\
\hline
\end{tabular}




\section{Results and Discussion}

\subsection{Impact-Oriented Analysis of Traditional Lightweight Aggregates}

Table 4 and Figure 3 show the impacts associated with the production of $1 \mathrm{~kg}$ of traditional lightweight aggregates made entirely of clay. The three clay samples separately obtained similar results to each other in all stages. A significant difference is observed in the manufacturing stage, due to differences in the sintering conditions of the aggregates according to the type of clay used. With regard to the impact categories, it should be noted that Global Warning Potential shows values very close to $0.37-0.38 \mathrm{~kg}$ eq. $\mathrm{CO}_{2} / \mathrm{kg}$ in emissions for SY, PY and PR, respectively. This is in line with other authors [53].

SY-0

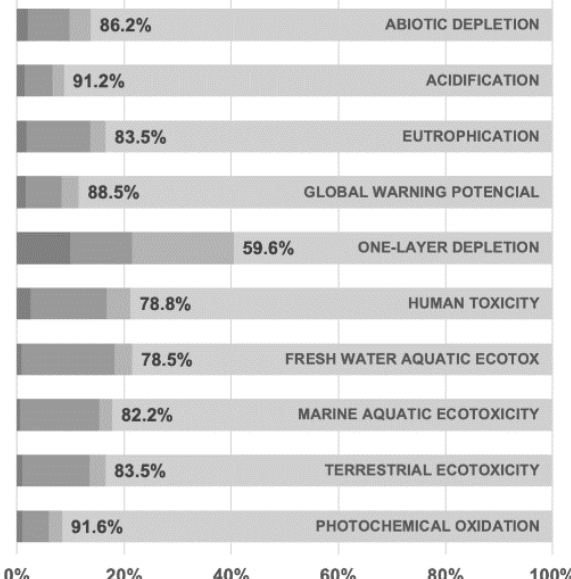

PY-0

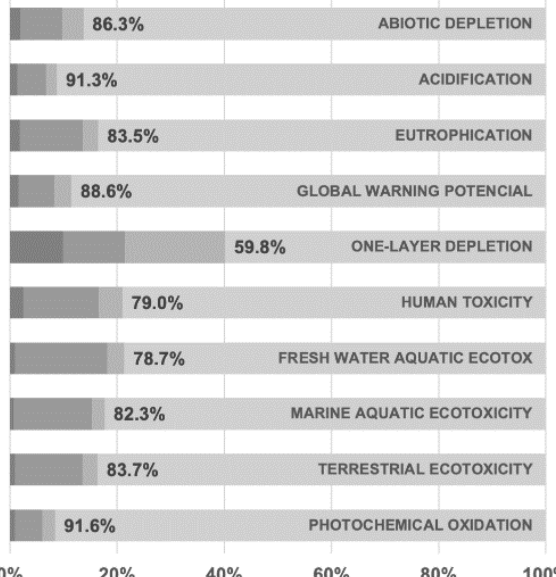

PR-0

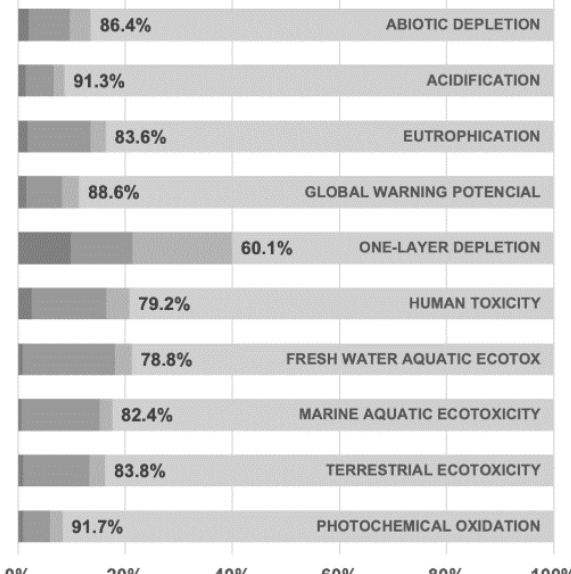

-RAW MATERIALS $=E X T R A C T I O N \quad$ "TRANSPORT $=$ MANUFACTURING

Figure 3. Contribution of characterized impacts associated with $1 \mathrm{~kg}$ of lightweight aggregates manufactured without any residue from different stages of production (Scenario 0).

Within this same category, the stage with the lowest contribution to the impact is that of raw materials, representing $2 \%$ of the total for all the clays studied. Something similar occurs with the extraction and transport stages, with obtained values of $7 \%$ and $3 \%$, respectively, for $\mathrm{CO}_{2}$ emissions. Undoubtedly, the manufacturing stage is the most responsible for the final impact, with a contribution of $89 \%$ ( $88 \%$ for SY). This is due to the long periods of time that kilns must remain at temperatures above $1000{ }^{\circ} \mathrm{C}$ and the consequent economic and environmental cost that this entails, which contributes to the higher combustion of fossil fuels responsible for powering kilns at such temperatures, as reported by authors who have analyzed the ceramics sector [52-54].

The remaining nine impact categories show variations of less than $1 \%$ for the three clays studied in the four stages. The One-Layer Depletion category stands out, where the contribution of raw materials increases up to $10 \%$ and $19 \%$ in the transport stage. Other authors have also found this effect [54] and have analyzed it $[53,55,56]$. They have found that it is due to emissions corresponding to the fuel consumption required for the operation of the extraction machinery and distribution vehicles, as well as the natural gas and electricity used in the atomization plants. Substances such as methane, bromotrifluoro-, Halon 1301, etc., would be the main culprits. This impact could be partially offset by the installation of on-site cogeneration systems. In the extraction process, the categories with the lowest contribution to the final impact are Acidification and Photochemical Oxidation, with 5\%. The Fresh Water Aquatic Ecotox and Marine Aquatic Ecotoxicity categories, with 17\% and 15\%, respectively, increased to make a significant contribution. The last manufacturing stage maintains all its contributions above the significant margin (>50\%), with minimum values for the One-Layer Depletion category $(60 \%)$ and more extreme values for Photochemical Oxidation and Acidification (92\% and $91 \%$, respectively) for the three types of clays. 
Table 4. Characterized impacts associated with $1 \mathrm{~kg}$ of lightweight aggregates incorporating 0 and $2.5 \mathrm{wt} \%$ of AHS, PS, CD and CG, respectively.

\begin{tabular}{|c|c|c|c|c|c|c|c|c|c|c|c|c|c|c|c|c|}
\hline & & & & & & AHS & & & PS & & & CD & & & CG & \\
\hline $\begin{array}{l}\text { Impact } \\
\text { Categories }\end{array}$ & Units & SY & PY & PR & $\begin{array}{c}\text { SY- } \\
\text { 2.5AHS }\end{array}$ & $\begin{array}{c}\text { PY- } \\
\text { 2.5AHS }\end{array}$ & $\begin{array}{c}\text { PR- } \\
\text { 2.5AHS }\end{array}$ & SY-2.5PS & PY-2.5PS & PR-2.5PS & SY-2.5CD & PY-2.5CD & PR-2.5CD & SY-2.5CG & PY-2.5CG & PR-2.5CG \\
\hline $\begin{array}{l}\text { Abiotic } \\
\text { Depletion }\end{array}$ & kg Sb eq & 0.002161234 & 0.002190064 & 0.002218064 & 0.001996073 & 0.001887901 & 0.001429863 & 0.002140307 & 0.002169157 & 0.002140307 & 0.002098587 & 0.002127427 & 0.002179207 & 0.001982762 & 0.002011595 & 0.001982762 \\
\hline Eutrophication & $\begin{array}{c}\mathrm{kg} \mathrm{PO}_{4}^{3-} \\
\quad \text { eq }\end{array}$ & 0.000465992 & 0.000472205 & 0.00047824 & 0.000425808 & 0.000402502 & 0.000303821 & 0.000460951 & 0.000467164 & 0.000460951 & 0.000450782 & 0.000456995 & 0.000468153 & 0.000422564 & 0.000428768 & 0.000422564 \\
\hline $\begin{array}{l}\text { Global } \\
\text { Warning } \\
\text { Potential }\end{array}$ & $\mathrm{kgCO}_{2}$ eq & 0.37264414 & 0.37771582 & 0.38264036 & 0.34545584 & 0.32643175 & 0.24587405 & 0.36922336 & 0.37429504 & 0.36922336 & 0.36234839 & 0.36742006 & 0.3765259 & 0.34326212 & 0.3483338 & 0.34326212 \\
\hline $\begin{array}{l}\text { One-Layer } \\
\text { Depletion }\end{array}$ & $\begin{array}{c}\mathrm{kg} \text { CFC-11 } \\
\text { eq }\end{array}$ & $\begin{array}{c}1.11172 \times \\
10^{-8}\end{array}$ & $\begin{array}{c}1.12239 \times \\
10^{-8}\end{array}$ & $\begin{array}{c}1.13276 \times \\
10^{-8}\end{array}$ & $\begin{array}{c}1.02959 \times \\
10^{-8}\end{array}$ & $\begin{array}{c}9.89541 \times \\
10^{-9} \times\end{array}$ & $\begin{array}{c}8.19949 \times \\
10^{-9}\end{array}$ & $\begin{array}{c}1.09936 \times \\
10^{-8}\end{array}$ & $\begin{array}{c}1.11004 \times \\
10^{-8}\end{array}$ & $\begin{array}{c}1.09936 \times \\
10^{-8}\end{array}$ & $\begin{array}{c}1.07918 \times \\
10^{-8}\end{array}$ & $\begin{array}{c}1.08986 \times \\
10^{-8}\end{array}$ & $\begin{array}{c}1.10903 \times \\
10^{-8}\end{array}$ & $\begin{array}{c}1.02316 \times \\
10^{-8}\end{array}$ & $\begin{array}{c}1.03384 \times \\
10^{-8}\end{array}$ & $\begin{array}{c}1.02316 \times \\
10^{-8}\end{array}$ \\
\hline $\begin{array}{l}\text { Human } \\
\text { Toxicity }\end{array}$ & $\begin{array}{l}\mathrm{kg} \text { 1.4-DB } \\
\text { eq }\end{array}$ & 0.13830491 & 0.13997269 & 0.14159208 & 0.12924357 & 0.12298765 & 0.0964969 & 0.13713118 & 0.13879896 & 0.13713118 & 0.13484962 & 0.1365174 & 0.13951178 & 0.12851555 & 0.13018332 & 0.12851555 \\
\hline $\begin{array}{l}\text { Fresh Water } \\
\text { Aquatic } \\
\text { Ecotox }\end{array}$ & $\begin{array}{c}\mathrm{kg} 1.4-\mathrm{DB} \\
\mathrm{eq}\end{array}$ & 0.0667779 & 0.0676351 & 0.06846743 & 0.06079543 & 0.05758001 & 0.04396431 & 0.06604148 & 0.06689868 & 0.06604148 & 0.06452401 & 0.06538121 & 0.06692027 & 0.06031123 & 0.06116843 & 0.06031123 \\
\hline $\begin{array}{l}\text { Marine } \\
\text { Aquatic } \\
\text { Ecotoxicity }\end{array}$ & $\begin{array}{l}\mathrm{kg} \text { 1.4-DB } \\
\text { eq }\end{array}$ & 145.8228294 & 147.746464 & 149.6142872 & 133.2497484 & 126.0341122 & 95.47942371 & 144.2809406 & 146.2045752 & 144.2809406 & 141.0900692 & 143.0137037 & 146.4674522 & 132.2315824 & 134.1552169 & 132.2315824 \\
\hline $\begin{array}{l}\text { Terrestrial } \\
\text { Ecotoxicity }\end{array}$ & $\begin{array}{c}\mathrm{kg} 1.4-\mathrm{DB} \\
\text { eq }\end{array}$ & 0.000862918 & 0.000874138 & 0.000885038 & 0.000799081 & 0.000756986 & 0.000578759 & 0.000855028 & 0.000866248 & 0.000855028 & 0.000838841 & 0.000850059 & 0.000870208 & 0.000793912 & 0.00080513 & 0.000793912 \\
\hline $\begin{array}{l}\text { Photochemical } \\
\text { Oxidation }\end{array}$ & $\begin{array}{c}\mathrm{kg} \mathrm{C}_{2} \mathrm{H}_{4} \\
\text { eq }\end{array}$ & 0.000121395 & 0.000123071 & 0.000124696 & 0.000113499 & 0.00010722 & $\begin{array}{c}8.06094 \times \\
10^{-5}\end{array}$ & 0.000120421 & 0.000122088 & 0.000120421 & 0.000118415 & 0.000120092 & 0.000123102 & 0.000112868 & 0.000114545 & 0.000112868 \\
\hline
\end{tabular}


The degree of influence for the raw materials stage would have a level B, although it would be possible to add different materials to the mixtures, as we show below. The manufacture of lightweight aggregates depends to a large extent on the physical-chemical properties of clays, so the substitution of this raw material could only be executed if a material with similar characteristics and behavior could be obtained. The extraction and transport phases would have a degree of influence C, since there would be no control, beyond the logistic one, that would allow influencing the performance of the activities. In contrast, the manufacturing stage would have a grade A. It is precisely in this stage with the greatest contribution to the impact where the greatest number of measures could be applied to reduce energy dependence. Some of these modifications could be the reduction in sintering times and temperatures, or more engineering measures where the hot air from the furnaces is stored in heat accumulators for later reuse. Or, as we discuss below, we could use the exothermic decomposition of organic wastes to reduce the energy input needed to reach the optimum sintering temperature.

To illustrate the following sections, Figures 4 and 5 show the environmental benefits of the mixture variants compared individually with the traditional clay mixture they modify.

\subsection{Impact-Oriented Analysis of Lightweight Aggregates Added with Wastes}

Table 4 shows the data obtained for aggregates incorporating $2.5 \mathrm{wt} \%$ AHS, PS, CP and CG. From these results, we can see how the addition of waste has a greater impact on the manufacturing and extraction category than on the raw materials and transport categories.

For extraction, the mixes incorporating 2.5\% AHS (Scenario 1) present an impact reduction of up to $60 \%$ when PR is added to the clay in the most benefited stages, namely, Abiotic Depletion, Acidification, Eutrophication, Global Warning Potential and One-Layer Depletion, as can be seen in Figure 4 a. This improvement reaches $40 \%$ for these same categories in the mixes with SY and PY. The improvement for the rest of the categories decreases between 15 and 20 points with respect to the data discussed above.

In Scenario 4, illustrated in Figure $4 d$, the overall improvement is in the same categories mentioned in the previous paragraph for the three clays analyzed and would be $40 \%$. In Scenarios 2 and 3, it is more negligible, being in the order of $4 \%$ for the extraction stage of Scenario 2 and 12\% in Scenario 3. The second stage that presents a greater reduction in environmental impact is the manufacturing stage (Figure 5), as discussed above and in other industry work [55,57]. Specifically, for Scenario 1 and PR clay, the improvement is $35 \%$, this being the mixture that presents the best results. However, the rest of the scenarios also show improvements in the order of $5-8 \%$ in Scenario 4 for the three types of clay, $0.5-3 \%$ for Scenario 3 and $1 \%$ for Scenario 2 . For the rest of the stages, raw materials and transport, the results are of little relevance, with improvements between $0 \%$ and $2.5 \%$.

If we were to evaluate the data globally and compare them with each other, we would obtain a visual as shown in Figure 6. From it, we can see how the mix of Scenario 1, specifically PR-2.5AHS (Figure 6c), represents a reduction in environmental impact of about $35 \%$ with respect to traditional aggregate. This figure is an average value of the impact reduction of all the categories analyzed. It would be followed by the PY-2.5AHS (Figure 6b) mix in the same scenario, with a reduction of $13.5 \%$. The PR-2.5CG, SY-2.5CG and PY-2.5CG mixes in Scenario 4 would have reductions of $10.5 \%, 8.2 \%$ and $8.1 \%$, respectively. Except for the SY-2.5AHS (Figure 6a) combination of Scenario 1 with a $7.6 \%$ reduction, the rest of the mixes are hardly appreciable improvements over the traditional aggregates evaluated. 


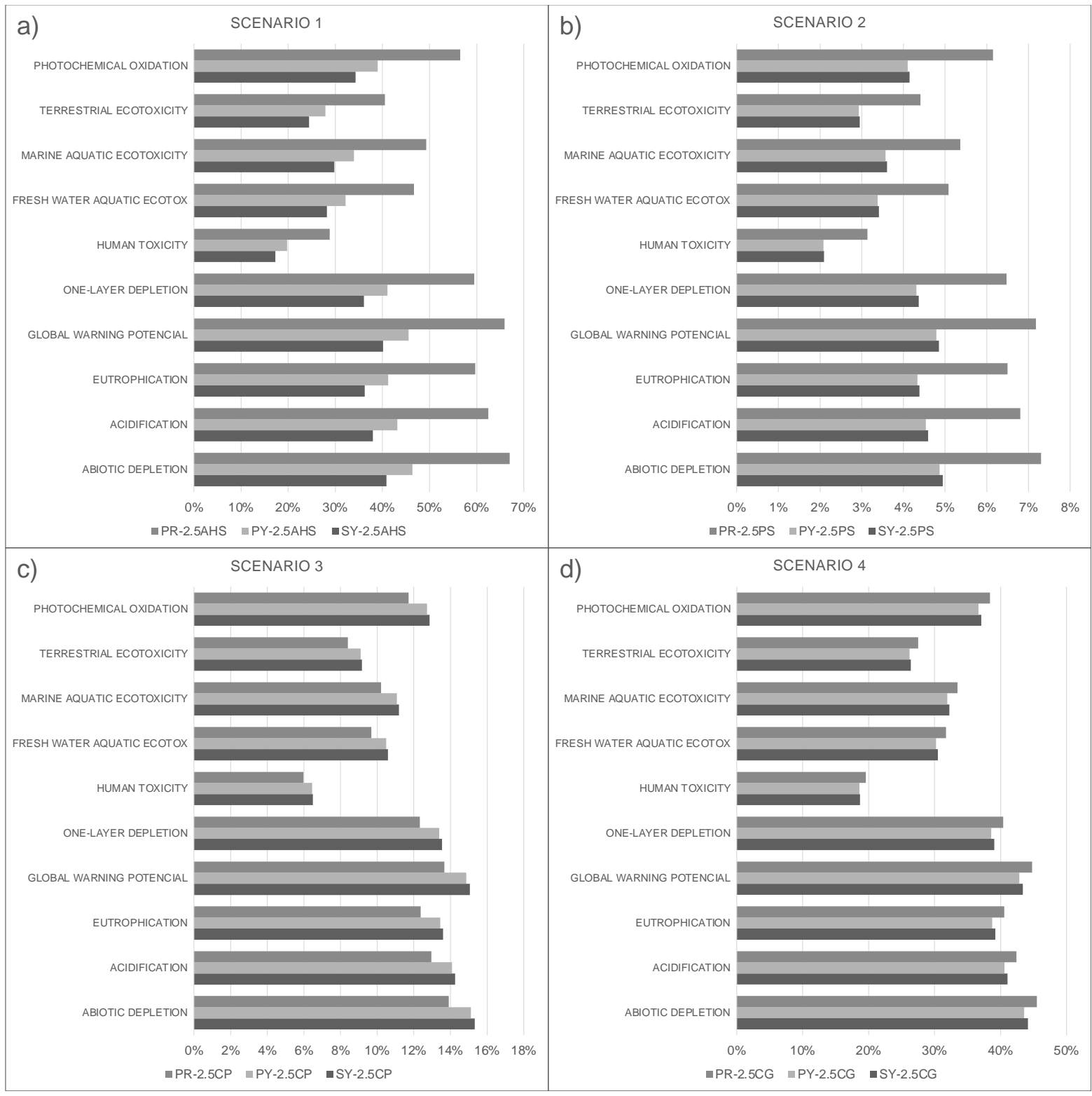

Figure 4. Comparison of the environmental benefits of the impacts characterized between light aggregates produced with $2.5 \mathrm{wt} \%$ waste in Scenarios 1 (a), 2 (b), 3 (c) and 4 (d) at the EXTRACTION stage.

\subsection{Standardized Analysis of Traditional and Residue-Added Lightweight Aggregates}

In parallel to the characterization analysis, a standardized analysis of the data was carried out to establish unitary criteria to compare the results with the emissions of an average European, as described in Section 2.2.3. Table 5 shows similar impact reduction results to those discussed in the previous section, except for an unusual result in the category of ecotoxicity of the marine environment, an unexpected value given that aggregate production does not represent a directly toxic activity for the marine environment. After an exhaustive search for the reasons, Heijungs et al. [58] concluded that this generalized phenomenon should not be considered an error in the study, but a bias in the category calculation system, as is the case in some similar studies [50,59-61]. 


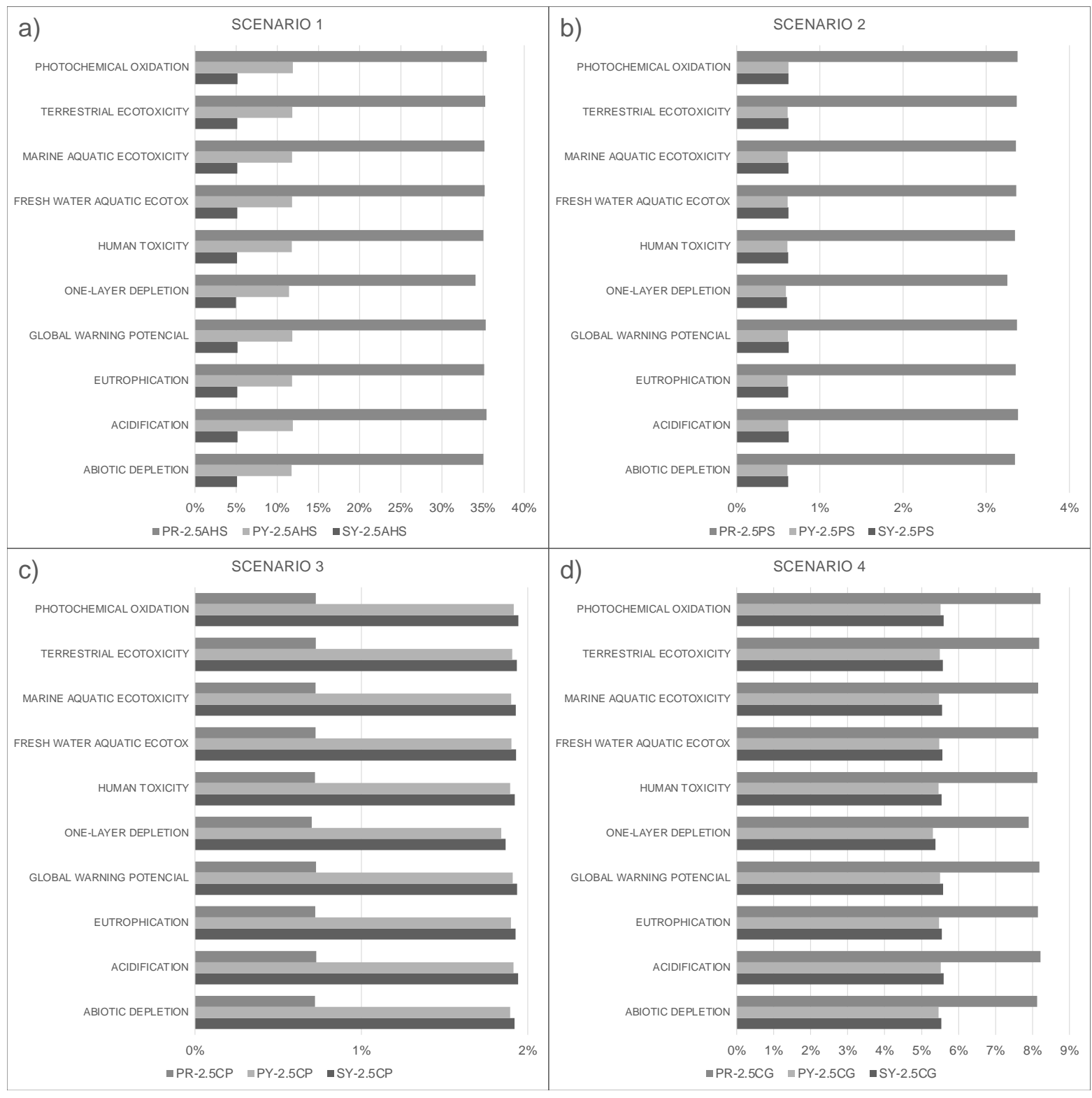

Figure 5. Comparison of the environmental benefits of the impacts characterized between light aggregates produced with $2.5 \mathrm{wt} \%$ waste in Scenarios 1 (a), 2 (b), 3 (c) and 4 (d) at the MANUFACTURING stage.

From the study in Table 5, it can be deduced that the incorporation of waste in the mixture for the manufacture of lightweight aggregates represents an advance in the reduction in the environmental impact generated by the production of this material. Proportions of residue in the mix higher than $2.5 \%$ could mean greater environmental benefits, but its effect on the technological properties of the material should be evaluated, and the optimum point between both should be found. Advancing sustainable products that are an improvement over previous ones is the greatest challenge facing material engineering today. 
a)

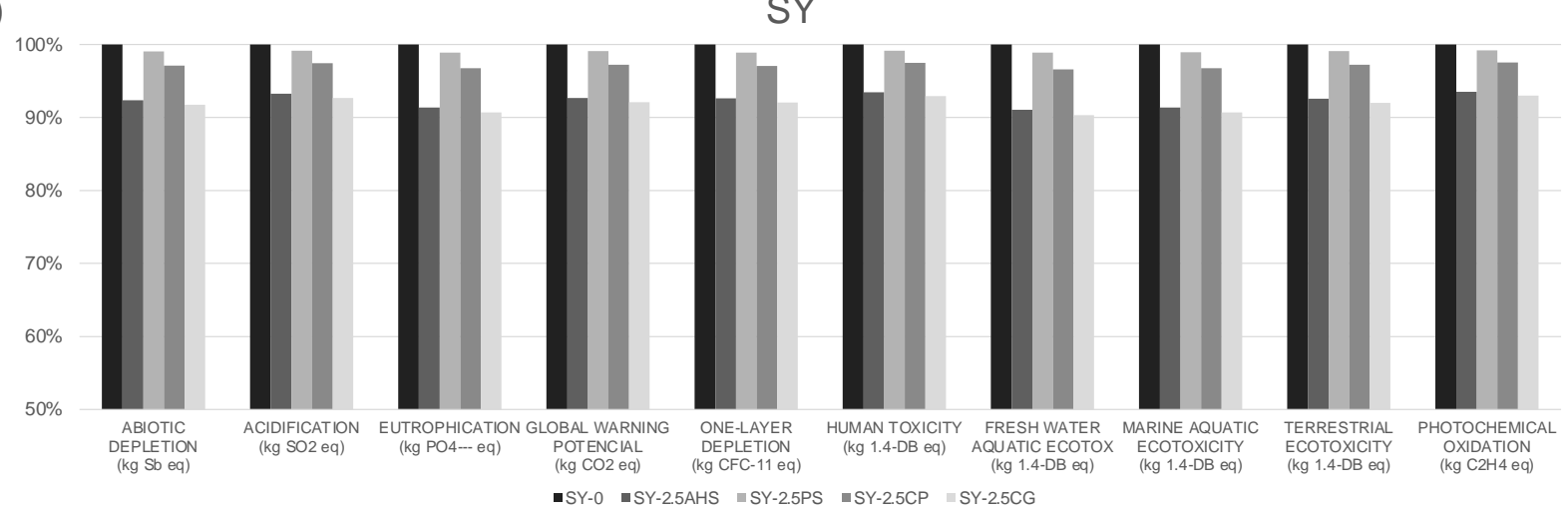

b)

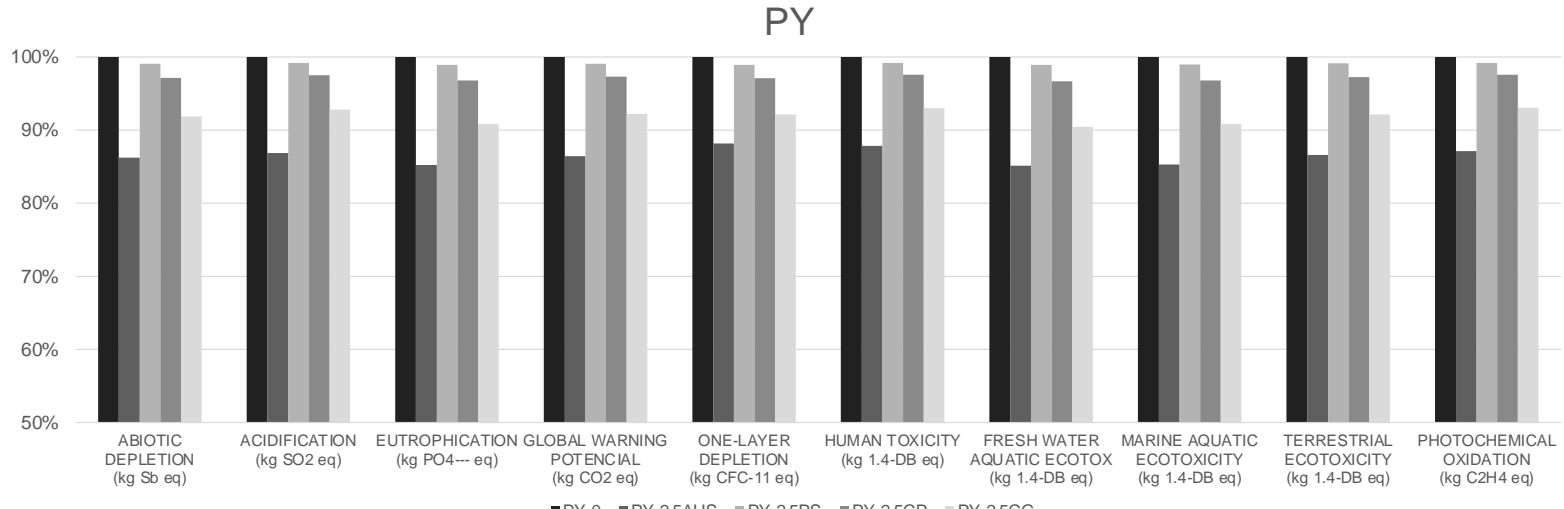

c)

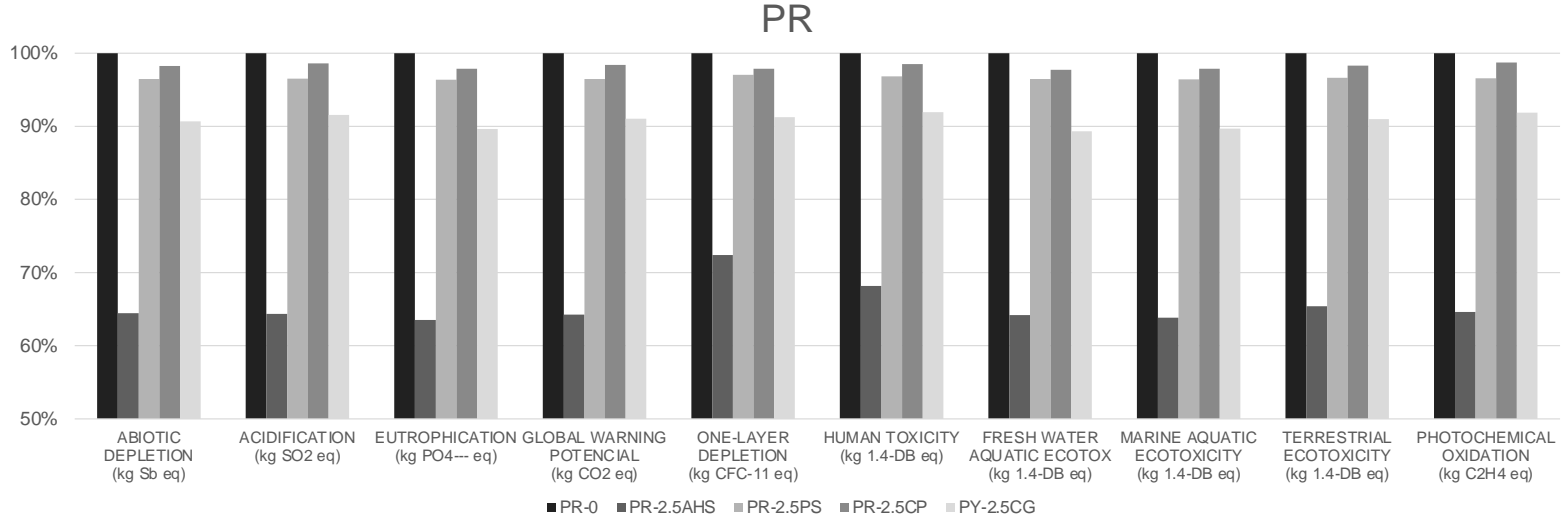

Figure 6. Characterized impact values of different impact categories of lightweight aggregates incorporating $2.5 \%$ of waste classified by clay type: SY (a), PY (b) and PR (c). 
Table 5. Normalized impacts associated with $1 \mathrm{~kg}$ of lightweight aggregates incorporating 0 and $2.5 \mathrm{wt} \%$ of AHS, PS, CD and CG, respectively.

\begin{tabular}{|c|c|c|c|c|c|c|c|c|c|c|c|c|c|c|c|c|}
\hline \multirow[b]{2}{*}{$\begin{array}{l}\text { Impact } \\
\text { Categories }\end{array}$} & \multirow[b]{2}{*}{ Units } & \multirow[b]{2}{*}{ SY } & \multirow[b]{2}{*}{ PY } & \multirow[b]{2}{*}{ PR } & \multicolumn{3}{|c|}{ AHS } & \multicolumn{3}{|c|}{ PS } & \multicolumn{3}{|c|}{ CD } & \multicolumn{3}{|c|}{ CG } \\
\hline & & & & & $\begin{array}{c}\text { SY- } \\
\text { 2.5AHS }\end{array}$ & $\begin{array}{c}\text { PY- } \\
\text { 2.5AHS }\end{array}$ & $\begin{array}{c}\text { PR- } \\
\text { 2.5AHS }\end{array}$ & SY-2.5PS & PY-2.5PS & PR-2.5PS & SY-2.5CD & PY-2.5CD & PR-2.5CD & SY-2.5CG & PY-2.5CG & PR-2.5CG \\
\hline $\begin{array}{l}\text { Abiotic } \\
\text { Depletion }\end{array}$ & $\mathrm{kg} \mathrm{Sb}$ eq & $\begin{array}{c}1.26436 \times \\
10^{-12}\end{array}$ & $\begin{array}{c}1.28123 \times \\
10^{-12}\end{array}$ & $\begin{array}{c}1.29756 \times \\
10^{-12}\end{array}$ & $\begin{array}{c}1.16767 \times \\
10^{-12}\end{array}$ & $\frac{1.10443 \times}{10^{-12}} \times$ & $\begin{array}{c}8.36474 \times \\
10^{-13}\end{array}$ & $\frac{1.25207 \times}{10^{-12}}$ & $\frac{1.26895 \times}{10^{-12}}$ & $\begin{array}{c}1.25207 \times \\
10^{-12}\end{array}$ & $\begin{array}{c}1.22766 \times \\
10^{-12}\end{array}$ & $\begin{array}{c}1.24453 \times \\
10^{-12}\end{array}$ & $\begin{array}{c}1.27482 \times \\
10^{-12}\end{array}$ & $\begin{array}{c}1.15991 \times \\
10^{-12}\end{array}$ & $\begin{array}{c}1.17678 \times \\
10^{-12}\end{array}$ & $\begin{array}{c}1.15991 \\
10^{-12}\end{array}$ \\
\hline Eutrophication & $\begin{array}{l}\mathrm{kg} \mathrm{PO}_{4}{ }^{3-} \\
\text { eq }\end{array}$ & $\begin{array}{l}9.2733 \times \\
10^{-13}\end{array}$ & $\begin{array}{c}9.3969 \times \\
10^{-13}\end{array}$ & $\begin{array}{c}9.517 \times \\
10^{-13}\end{array}$ & $\begin{array}{c}8.47348 \times \\
10^{-13}\end{array}$ & $\begin{array}{c}8.00979 \times \\
10^{-13}\end{array}$ & $\begin{array}{c}6.04608 \times \\
10^{-13}\end{array}$ & $\begin{array}{c}9.17291 \times \\
10^{-13}\end{array}$ & $\begin{array}{c}9.29651 \times \\
10^{-13}\end{array}$ & $\begin{array}{c}9.17291 \times \\
10^{-13}\end{array}$ & $\begin{array}{c}8.9706 \times \\
10^{-13}\end{array}$ & $\begin{array}{c}9.0942 \times \\
10^{-13} \times\end{array}$ & $\begin{array}{c}9.31613 \times \\
10^{-13} \times\end{array}$ & $\begin{array}{c}8.40896 \times \\
10^{-13}\end{array}$ & $\begin{array}{c}8.53257 \times \\
10^{-13}\end{array}$ & $\begin{array}{c}8.40896 \times \\
10^{-13}\end{array}$ \\
\hline $\begin{array}{l}\text { Global } \\
\text { Warning } \\
\text { Potential }\end{array}$ & $\mathrm{kgCO}_{2}$ eq & $\frac{1.47568 \times}{10^{-12}}$ & $\frac{1.49573 \times}{10^{-12}}$ & $\begin{array}{c}1.51525 \times \\
10^{-13}\end{array}$ & $\begin{array}{c}1.36799 \times \\
10^{-12}\end{array}$ & $\frac{1.29268 \times}{10^{-12}}$ & $\frac{9.73659 \times}{10^{-13}}$ & $\frac{1.46208 \times}{10^{-12}}$ & $\frac{1.48224 \times}{10^{-12}}$ & $\frac{1.46208 \times}{10^{-12}}$ & $\frac{1.43489 \times}{10^{-12}}$ & $\begin{array}{c}1.45495 \times \\
10^{-12}\end{array}$ & $\frac{1.491 \times}{10^{-12}}$ & $\begin{array}{c}1.35927 \times \\
10^{-12}\end{array}$ & $\frac{1.37943 \times}{10^{-12}}$ & $\frac{1.35927}{10^{-12}} \times$ \\
\hline $\begin{array}{l}\text { Human } \\
\text { Toxicity }\end{array}$ & $\begin{array}{c}\mathrm{kg} 1.4-\mathrm{DB} \\
\text { eq }\end{array}$ & $\frac{7.35789 \times}{10^{-13}} \times$ & $\frac{7.44659 \times}{10^{-13}}$ & $\underset{7.53269 \times}{10^{-13}}$ & $\begin{array}{c}6.87581 \times \\
10^{-13}\end{array}$ & $\begin{array}{c}6.54291 \times \\
10^{-13} \times\end{array}$ & $\frac{5.13359 \times}{10^{-13}}$ & $\underset{10^{-13}}{7.29539} \times$ & $\begin{array}{c}7.38419 \times \\
10^{-13}\end{array}$ & $\begin{array}{c}7.29539 \times \\
10^{-13} \times\end{array}$ & $\begin{array}{c}7.17402 \times \\
10^{-13}\end{array}$ & $\underset{10^{-13}}{7.26272 \times}$ & $\underset{10^{-13}}{7.4226 \times}$ & $\frac{6.83708 \times}{10^{-13}}$ & $\underset{10^{-13}}{6.92579 \times}$ & $\underset{10^{-13}}{6.83708 \times}$ \\
\hline $\begin{array}{l}\text { Fresh Water } \\
\text { Aquatic } \\
\text { Ecotox }\end{array}$ & $\begin{array}{c}\text { kg } 1.4-D B \\
\text { eq }\end{array}$ & $\begin{array}{c}8.88149 \\
10^{-12}\end{array}$ & $\begin{array}{c}8.99539 \times \\
10^{-12}\end{array}$ & $\frac{9.10619 \times}{10^{-12}} \times$ & $\begin{array}{c}8.08586 \times \\
10^{-12}\end{array}$ & $\underset{10^{-12}}{7.65816} \times$ & $\begin{array}{c}5.84721 \times \\
10^{-12}\end{array}$ & $\begin{array}{c}8.78346 \times \\
10^{-12}\end{array}$ & $\begin{array}{c}8.89756 \times \\
10^{-12}\end{array}$ & $\begin{array}{c}8.78346 \times \\
10^{-12}\end{array}$ & $\begin{array}{c}8.58166 \times \\
10^{-12}\end{array}$ & $\begin{array}{c}8.69566 \times \\
10^{-12}\end{array}$ & $\begin{array}{c}8.90036 \times \\
10^{-12}\end{array}$ & $\begin{array}{c}8.02146 \times \\
10^{-12}\end{array}$ & $\begin{array}{c}8.13536 \times \\
10^{-12}\end{array}$ & $\begin{array}{c}8.02146 \times \\
10^{-12}\end{array}$ \\
\hline $\begin{array}{l}\text { Marine } \\
\text { Aquatic } \\
\text { Ecotoxicity }\end{array}$ & $\begin{array}{c}\mathrm{kg} \text { 1.4-DB } \\
\text { eq }\end{array}$ & $\begin{array}{l}4.57879 \times \\
10^{-11}\end{array}$ & $\underset{10^{-11}}{4.63924 \times}$ & $\frac{4.69791 \times}{10^{-11}}$ & $\begin{array}{l}4.18405 \times \\
10^{-11}\end{array}$ & $\begin{array}{c}3.95743 \times \\
10^{-11}\end{array}$ & $\frac{2.99809 \times}{10^{-11}}$ & $\begin{array}{l}4.53038 \times \\
10^{-11}\end{array}$ & $\frac{4.59083 \times}{10^{-11}}$ & $\begin{array}{l}4.53038 \times \\
10^{-11}\end{array}$ & $\begin{array}{l}4.43027 \times \\
10^{-11}\end{array}$ & $\begin{array}{l}4.49062 \times \\
10^{-11} \times\end{array}$ & $\begin{array}{c}4.59912 \times \\
10^{-11}\end{array}$ & $\begin{array}{c}4.15207 \times \\
10^{-12}\end{array}$ & $\begin{array}{l}4.21242 \times \\
10^{-11}\end{array}$ & $\begin{array}{c}4.15207 \times \\
10^{-11}\end{array}$ \\
\hline $\begin{array}{l}\text { Terrestrial } \\
\text { Ecotoxicity }\end{array}$ & $\begin{array}{c}\mathrm{kg} 1.4-\mathrm{DB} \\
\mathrm{eq}\end{array}$ & $\begin{array}{c}9.40584 \times \\
10^{-13}\end{array}$ & $\begin{array}{c}9.52814 \times \\
10^{-13}\end{array}$ & $\begin{array}{c}9.64694 \times \\
10^{-13} \times\end{array}$ & $\begin{array}{c}8.70988 \times \\
10^{-13}\end{array}$ & $\begin{array}{l}8.2512 \times \\
10^{-13} \times\end{array}$ & $\begin{array}{c}6.30855 \times \\
10^{-13}\end{array}$ & $\begin{array}{c}9.31976 \times \\
10^{-13}\end{array}$ & $\begin{array}{c}9.44206 \times \\
10^{-13}\end{array}$ & $\begin{array}{c}9.31976 \times \\
10^{-13}\end{array}$ & $\begin{array}{c}9.14336 \times \\
10^{-13}\end{array}$ & $\begin{array}{c}9.26566 \times \\
10^{-13}\end{array}$ & $\begin{array}{c}9.48526 \times \\
10^{-13}\end{array}$ & $\begin{array}{c}8.65366 \times \\
10^{-13}\end{array}$ & $\begin{array}{c}8.77599 \\
10^{-13}\end{array}$ & $\begin{array}{c}8.65366 \times \\
10^{-13}\end{array}$ \\
\hline $\begin{array}{l}\text { Photochemical } \\
\text { Oxidation }\end{array}$ & $\begin{array}{c}\mathrm{kg} \mathrm{C}_{2} \mathrm{H}_{4} \\
\text { eq }\end{array}$ & $\begin{array}{c}6.66466 \times \\
10^{-13}\end{array}$ & $\begin{array}{c}6.75663 \times \\
10^{-13} \times\end{array}$ & $\frac{6.84598 \times}{10^{-13}}$ & $\begin{array}{c}6.23132 \times \\
10^{-13} \times\end{array}$ & $\underset{10^{-13}}{5.88639 \times}$ & $\begin{array}{c}4.42544 \times \\
10^{-13}\end{array}$ & $\begin{array}{c}6.61091 \times \\
10^{-13} \times\end{array}$ & $\begin{array}{c}6.70287 \times \\
10^{-13} \times\end{array}$ & $\begin{array}{c}6.61091 \times \\
10^{-13}\end{array}$ & $\begin{array}{c}6.5011 \times \\
10^{-13} \times\end{array}$ & $\begin{array}{c}6.59306 \times \\
10^{-13}\end{array}$ & $\begin{array}{c}6.75823 \times \\
10^{-13}\end{array}$ & $\begin{array}{c}6.19634 \times \\
10^{-13}\end{array}$ & $\begin{array}{c}6.2883 \times \\
10^{-13} \times\end{array}$ & $\begin{array}{c}6.19634 \times \\
10^{-13}\end{array}$ \\
\hline
\end{tabular}




\section{Conclusions}

Throughout the study, it has been possible to glimpse the environmental implications of the partial substitution of three natural clays for different wastes in the manufacture of lightweight ceramic aggregates. In order to determine the environmental impact of this product, the Life Cycle Assessment methodology was applied within the impact categories included in the framework of the CML 2000. Data extracted from laboratory, reference sources and databases such as Ecoinvent were used, processed by SimaPro and subsequently interpreted, always in accordance with the guidelines of the ISO 14040 standard.

The results obtained in this research allow us to conclude that the addition of organic wastes (nutshells, paper sewage sludge, cork dust and coffee grounds) in the mix represents an improvement over the traditional aggregate (without residue) with which it is compared, although in some cases, this improvement is slight. Of the wastes analyzed, the aggregates with almond and hazelnut shells proved to be the option that would have the least impact on the environment, with reductions exceeding 30\% in the most pronounced cases, but remaining at an average of $15 \%$. This, together with coffee grounds, would be the wastes that have proven to be the most efficient in reducing the carbon footprint in the manufacture of ceramic materials under conditions of sintering at high temperatures and reduced times.

Although one might expect that the addition of paper sewage sludge and paper cork dust would represent considerable improvements due to their high exothermic power, the overall calculation indicates that such improvements would be negligible. They present maximum values that barely reach a $3 \%$ improvement.

The great worldwide abundance of waste such as coffee grounds could be partly diminished by their use in high-demand products. Pellets for consumption in boilers or lightweight aggregates, as we have observed in this study, would be an optimal end with which to seek energy efficiency. The positive change in direction that the world is experiencing towards awareness of sustainability and the reuse of waste materials opens up a range of possibilities with an interesting horizon.

Author Contributions: Conceptualization, T.C.-P. and C.M.-G.; methodology, M.U.-R. and A.B.L.-G.: software, M.U.-R.; validation, M.U.-R., A.B.L.-G., J.M.M.-M. and C.J.C.-C.; formal analysis, M.U.-R.; investigation, M.U.-R. and A.B.L.-G.; resources, M.U.-R.; data curation, M.U.-R. and A.B.L.-G.; writing—original draft preparation, M.U.-R.; writing—review and editing, M.U.-R., A.B.L.-G. and J.M.M.-M.; visualization, C.M.-G.; supervision, T.C.-P.; project administration, C.M.-G.; funding acquisition, T.C.-P. and C.M.-G. All authors have read and agreed to the published version of the manuscript.

Funding: This research was conducted as a part of the ECO-MET-AL Project (PID2019-109520RB-I00). "Can industrial and mining metalliferous wastes produce green lightweight aggregates? Applying the Circular Economy" funded by the Spanish Ministry of Science, Innovation and Universities.

Institutional Review Board Statement: Not applicable.

Informed Consent Statement: Not applicable.

Data Availability Statement: Data is contained within the article.

Acknowledgments: This research was conducted as a part of the ECO-MET-AL Project (PID2019109520RB-I00), "Can industrial and mining metalliferous wastes produce green lightweight aggregates? Applying the Circular Economy" funded by the Spanish Ministry of Science, Innovation and Universities and ERDF funds, framed in the "Ayudas a 'Proyectos I + D + i' en el marco de los Programas Estatales de Generación de Conocimiento y Fortalecimiento Científico y Tecnológico del Sistema de I + D + i y de I + D + i orientada a los Retos de la Sociedad, Convocatoria 2019". The authors also gratefully acknowledge the technical and human support provided by CICT of the University of Jaén and the University of Málaga (UJA, MINECO, Junta de Andalucía, FEDER).

Conflicts of Interest: The authors declare no conflict of interest. 


\section{References}

1. Falcone, P.M.; Imbert, E. Social Life Cycle Approach as a Tool for Promoting the Market Uptake of Bio-Based Products from a Consumer Perspective. Sustainability 2018, 10, 1031. [CrossRef]

2. Falcone, P.M.; Imbert, E.; Sica, E.; Morone, P. Towards a bioenergy transition in Italy? Exploring regional stakeholder perspectives towards the Gela and Porto Marghera biorefineries. Energy Res. Soc. Sci. 2021, 80, 102238. [CrossRef]

3. Morone, P.; Falcone, P.M.; Tartiu, V.E. Food waste valorisation: Assessing the effectiveness of collaborative research networks through the lenses of a COST action. J. Clean. Prod. 2019, 238, 117868. [CrossRef]

4. Diamantis, D.; Eftaxias, A.; Stamatelatou, K.; Noutsopoulos, C.; Vlachokostas, C.; Aivasidis, A. Bioenergy in the era of circular economy: Anaerobic digestion technological solutions to produce biogas from lipid-rich wastes. Renew. Energy 2021, 168, $438-447$. [CrossRef]

5. Sharma, H.B.; Vanapalli, K.R.; Samal, B.; Sankar Cheela, V.R.; Dubey, B.K.; Bhattacharya, J. Circular economy approach in solid waste management system to achieve UN-SDGs: Solutions for post-COVID recovery. Sci. Total Environ. 2021, 800, 149605. [CrossRef]

6. European Commission. Report from the Commission to the Council and the European Parliament on Implementation of the Community Waste Legislation; COM (2006) 406 Final; Commission of the European Communities: Brussels, Belgium, 2006.

7. European Commission. A New Circular Economy Action Plan for a Cleaner and More Competitive Europe; COM (2020) 98 Final; Commission of the European Communities: Brussels, Belgium, 2020.

8. Ab Rahman, N.N.N.; Omar, F.M.; Ab Kadir, M.O. Chapter: Environmental aspects and impacts of construction industry. In Impact Monitoring and Management of Environmental Pollution, 1st ed.; Nova Science Publishers: Hauppauge, NY, USA, 2010; pp. 41-60, ISBN 978-1-60876-487-7.

9. ANEFA. El Sector (The Aggregate Sector in Spain). Asociación Nacional de Empresarios Fabricantes de Áridos. 2019. Available online: http:/ / www.aridos.org/el-sector/ (accessed on 19 November 2021).

10. Ayati, B.; Ferrándiz-Mas, V.; Newport, D.; Cheeseman, C. Use of clay in the manufacture of lightweight aggregate. Constr. Build. Mater. 2018, 162, 124-131. [CrossRef]

11. ESCSI. Applications. Expanded Shale, Clay and Slate Institute. 2018. Available online: https://www.escsi.org/applications/ (accessed on 17 October 2021).

12. EN 13055-1:2002; Lightweight Aggregates-Part 1: Lightweight Aggregates for Concrete, Mortar and Grout. ISO: Geneva, Switzerland, 2002.

13. Dondi, M.; Cappellettib, P.; D’Amore, M.; de Gennaro, R.; Graziano, S.F.; Langella, A.; Raimondo, M.; Zanellia, C. Lightweight aggregates from waste materials: Reappraisal of expansion behavior and prediction schemes for bloating. Constr. Build. Mater. 2016, 127, 394-409. [CrossRef]

14. Andreola, F.; Borghi, A.; Pedrazzi, S.; Allesina, G.; Tartarini, P.; Lancellotti, I.; Barbieri, L. Spent Coffee Grounds in the Production of Lightweight Clay Ceramic Aggregates in View of Urban and Agricultural Sustainable Development. Materials 2019, 12, 3581. [CrossRef]

15. Barbi, S.; Barbieri, F.; Andreola, F.; Lancellotti, I.; Martínez García, C.; Cotes Palomino, T.; Montorsi, M.; Barbieri, L. Design and characterization of controlled release PK fertilizers from agro-residues. Environ. Eng. Manag. J. 2020, 19, 1669-1676. [CrossRef]

16. Ricciardi, P.; Cillari, G.; Carnevale Miino, M.; Collivignarelli, M.C. Valorization of agro-industry residues in the building and environmental sector: A review. Waste Manag. Res. 2020, 38, 487-513. [CrossRef]

17. Faustino, J.; Silva, E.; Pinto, J.; Soares, E.; Cunha, V.M.C.F.; Soaresa, S. Lightweight concrete masonry units based on processed granulate of corn cob as aggregate. Mater. Constr. 2015, 65, e055. [CrossRef]

18. Farias, R.D.; Martínez García, C.; Cotes Palomino, T.; Andreola, F.; Lancellotti, I.; Barbieri, L. Valorization of agro-industrial wastes in lightweight aggregates for agronomic use: Preliminary study. Environ. Eng. Manag. J. 2017, 16, 1691-1699. [CrossRef]

19. Li, B.D.; Jian, S.W.; Zhu, J.Q.; Gao, X.; Gao, W.B. Effect of sintering temperature on lightweight aggregates manufacturing from copper contaminated soil. Ceram. Int. 2021, 47, 31319-31328. [CrossRef]

20. Bouachera, R.; Kasimi, R.; Ibnoussina, M.; Hakkou, R.; Taha, Y. Reuse of sewage sludge and waste glass in the production of lightweight aggregates. Mater. Today Proc. 2021, 37, 3866-3870. [CrossRef]

21. Balapour, M.; Rao, R.; Garboczi, E.J.; Spatari, S.; Hsuan, Y.G.; Billen, P.; Farnam, Y. Thermochemical principles of the production of lightweight aggregates from waste coal bottom ash. J. Am. Ceram. Soc. 2021, 104, 613-634. [CrossRef]

22. Bayoussef, A.; Loutou, M.; Taha, Y.; Mansori, M.; Benzaazoua, M.; Manoun, B.; Hakkou, R. Use of clays by-products from phosphate mines for the manufacture of sustainable lightweight aggregates. J. Clean. Prod. 2021, 280, 124361. [CrossRef]

23. Micke, W. Almond Production Manual; University of California: Oakland, CA, USA, 1996.

24. International Nut\&Dried Fruit. Global Statistical Review 2014/2015. 2015. Available online: https:/ / www.nutfruit.org/files/ tech/global-statistical-review-2014-2015_101779.pdf (accessed on 29 November 2021).

25. Universitat Politèctica de València. Residuos y Subproductos de la Industria Agroalimentaria. Available online: http://www.upv. es/resiagri/grupo04.html (accessed on 9 October 2021).

26. García, R.; Gil, M.V.; Rubiera, F.; Pevida, C. Pelletization of wood and alternative residual biomass blends for producing industrial quality pellets. Fuel 2019, 251, 739-753. [CrossRef]

27. Cataldo, S.; Gianguzza, A.; Milea, D.; Muratore, N.; Pettignano, A.; Sammartano, S. A critical approach to the toxic metal ion removal by hazelnut and almond shells. Environ. Sci. Pollut. Res. 2017, 25, 4238-4253. [CrossRef] [PubMed] 
28. Bulut, Y.; Tez, Z. Adsorption studies on ground shells of hazelnut and almond. J. Hazard. Mater. 2007, 149, 35-41. [CrossRef] [PubMed]

29. ASPAPEL. Guía de Gestion de Residuos (Fábricas de Pasta, Papel y Castón). Available online: http:/ / www.aspapel.es/ sites / default/files/publicaciones/Doc\%2084.pdf (accessed on 9 October 2021).

30. Silva, S.P.; Sabino, M.A.; Fernandes, E.M.; Correlo, V.M.; Boesel, L.F.; Reis, R.L. Cork: Properties, capabilities and applications. Int. Mater. Rev. 2005, 50, 345-365. [CrossRef]

31. Gandini, A.; Neto, C.P.; Silvestre, A.J.D. Suberin: A promising renewable resource for novel macromolecular materials. Prog. Polym. Sci. 2006, 31, 878-892. [CrossRef]

32. Mussatto, S.I.; Machado, E.M.S.; Martins, S.; Teixeira, J.A. Production, Composition, and Application of Coffee and Its Industrial Residues. Food Bioprocess Technol. 2011, 4, 661. [CrossRef]

33. Tokimoto, T.; Kawasaki, N.; Nakamura, T.; Akutagawa, J.; Tanada, S. Removal of lead ions in drinking water by coffee grounds as vegetable biomass. J. Colloid Interface Sci. 2005, 281, 56-61. [CrossRef]

34. Pfluger, R.A. Soluble coffee processing. In Solid Wastes: Origin, Collection, Processing, and Disposal, 1st ed.; Mantell, C.L., Ed.; Wiley: New York, NY, USA, 1975.

35. Saberian, M.; Li, J.; Donnoli, A.; Bonderenko, E.; Oliva, P.; Gill, B.; Lockrey, S.; Siddique, R. Recycling of spent coffee grounds in construction materials: A review. J. Clean. Prod. 2021, 289, 125837. [CrossRef]

36. CEN-EN 13055-2; Lightweight Aggregates-Part 2: Lightweight Aggregates for Bituminous Mixtures and Surface Treatments and for Unbound and Bound Applications. ISO: Geneva, Switzerland, 2002.

37. Curran, M.A. Life Cycle Assessment: A review of the methodology and its application to sustainability. Curr. Opin. Chem. Eng. 2013, 2, 273-277. [CrossRef]

38. ISO 14040; Environmental Management_Life Cycle Assessment_Principles and Framework. ISO: Geneva, Switzerland, 2006.

39. ISO 14044; Environmental Management—Life Cycle Assessment-Requirements and Guidelines. ISO: Geneva, Switzerland, 2006.

40. López-Aguilar, H.A.; Huerta-Reynoso, E.A.; Gómez, J.A.; Olivarez-Ramírez, J.M.; Duarte-Moller, A.; Pérez-Hernández, A. Life cycle assessment of regional brick manufacture. Mater. Constr. 2016, 66, 322. [CrossRef]

41. Muñoz, I.; Cifrian, E.; Andrés, A.; San Miguel, G.; Ruiz, D.; Viguri, J.R. Analysis of environmental benefits associated with the incorporation of Waelz slag into fired bricks using LCA. Constr. Build. Mater. 2018, 168, 178-186. [CrossRef]

42. Shi, X.; Mukhopadhyay, A.; Zollinger, D.; Grasley, Z. Economic input-output life cycle assessment of concrete pavement containing recycled concrete aggregate. J. Clean. Prod. 2019, 225, 414-425. [CrossRef]

43. Uceda-Rodríguez, M.; López-García, A.B.; Moreno-Maroto, J.M.; Cobo-Ceacero, C.J.; Cotes-Palomino, M.T.; Martínez García, C. Evaluation of the Environmental Benefits Associated with the Addition of Olive Pomace in the Manufacture of Lightweight Aggregates. Materials 2020, 13, 2351. [CrossRef]

44. López-García, A.B.; Cotes-Palomino, M.T.; Uceda-Rodríguez, M.; Moreno-Maroto, J.M.; Cobo-Ceacero, C.J.; Andreola, N.M.F.; Martínez-García, C. Application of Life Cycle Assessment in the Environmental Study of Sustainable Ceramic Bricks Made with 'alperujo' (Olive Pomace). Appl. Sci. 2021, 11, 2278. [CrossRef]

45. Moreno-Maroto, J.M.; Uceda-Rodríguez, M.; Cobo-Ceacero, C.J.; Calerode Hoces, M.; MartínLara, M.A.; Cotes-Palomino, T.; López García, A.B.; Martínez-García, C. Recycling of 'alperujo' (olive pomace) as a key component in the sintering of lightweight aggregates. J. Clean. Prod. 2019, 239, 118041. [CrossRef]

46. Moreno-Maroto, J.M.; Uceda-Rodríguez, M.; Cobo-Ceacero, C.J.; Cotes-Palomino, M.T.; Martínez-García, C.; Alonso-Azcárate, J. Studying the feasibility of a selection of Southern European ceramic clays for the production of lightweight aggregates. Constr. Build. Mater. 2020, 237, 117583. [CrossRef]

47. EN 14918:2009; Solid Biofuels-Determination of Calorific Value. European Committee for Standardization: Brussels, Belgium, 2009.

48. Frischknecht, R.; Rebitzer, G. The ecoinvent database system: A comprehensive web-based LCA database. J. Clean. Prod. 2005, 13, 1337-1343. [CrossRef]

49. Ingrao, C.; Selvaggi, R.; Valenti, F.; Matarazzo, A.; Pecorino, B.; Arcidiacono, C. Life cycle assessment of expanded clay granulate production using different fuels. Resour. Conserv. Recycl. 2019, 141, 398-409. [CrossRef]

50. Napolano, L.; Menna, C.; Graziano, S.F.; Asprone, D.; D’Amore, M.; de Gennaro, R.; Dondi, M. Environmental life cycle assessment of lightweight concrete to support recycled materials selection for sustainable design. Constr. Build. Mater. 2016, 119, 370-384. [CrossRef]

51. De Bruijn, H.; van Duin, R.; Huijbregts, M.A.J.; Guinee, J.B.; Gorree, M.; Heijungs, R.; Huppes, G.; Kleijn, R.; de Koning, A.; van Oers, L.; et al. Handbook on Life Cycle Assessment: Operational Guide to the ISO Standards, 1st ed.; Eco-Efficiency in Industry and Science; Kluwer Academic Publishers: Dordrecht, The Netherlands, 2002; p. 692. [CrossRef]

52. Ibáñez-Forés, V.; Bovea, M.D.; Azapagic, A. Assessing the sustainability of Best Available Techniques (BAT): Methodology and application in the ceramic tiles industry. J. Clean. Prod. 2013, 51, 162-176. [CrossRef]

53. Özkan, A.; Günkaya, Z.; Tok, G.; Karacasulu, L.; Metesoy, M.; Banar, M.; Kara, A. Life Cycle Assessment and Life Cycle Cost Analysis of Magnesia Spinel Brick Production. Sustainability 2016, 8, 662. [CrossRef]

54. Almeida, M.I.; Dias, A.C.; Demertzi, M.; Arroja, L. Environmental profile of ceramic tiles and their potential for improvement. J. Clean. Prod. 2016, 131, 583-593. [CrossRef] 
55. Ibáñez-Forés, V.; Bovea, M.D.; Simó, A. Life cycle assessment of ceramic tiles. Environmental and statistical analysis. Int. J. Life Cycle Assess. 2011, 16, 916. [CrossRef]

56. Ferrari, A.M.; Volpi, L.; Pini, M.; Siligardi, C.; García-Muiña, F.E.; Settembre-Blundo, D. Building a Sustainability Benchmarking Framework of Ceramic Tiles Based on Life Cycle Sustainability Assessment (LCSA). Resources 2019, 8, 11. [CrossRef]

57. Sappa, G.; Iacurto, S.; Ponzi, A.; Tatti, F.; Torretta, V.; Viotti, P. The LCA Methodology for Ceramic Tiles Production by Addition of MSWI BA. Resources 2019, 8, 93. [CrossRef]

58. Heijungs, R.; Guinée, J.; Kleijn, R. Bias in normalization: Causes, consequences, detection and remedies. Int. J. Life Cycle Assess. 2007, 12, 211. [CrossRef]

59. Pulselli, R.M.; Ridolfi, R.; Rugani, B.; Tiezzi, E. Application of life cycle assessment to the production of man-made crystal glass. Int. J. Life Cycle Assess. 2009, 14, 490-501. [CrossRef]

60. Konstantzos, G.E.; Malamis, D.; Sotiropoulos, A.; Loizidou, M. Environmental profile of an innovative household biowaste dryer system based on Life Cycle Assessment. Waste Manag. Res. 2018, 37, 48-58. [CrossRef] [PubMed]

61. Behrooznia, L.; Sharifi, M.; Alimardani, R.; Mousavi-Avval, S.H. Sustainability analysis of landfilling and composting-landfilling for municipal solid waste management in the north of Iran. J. Clean. Prod. 2018, 203, 1028-1038. [CrossRef] 